and I think the poundal, as units of energy " looks as if I confuse force and energy. The context shows that I object to non-metric units as unscientific, and therefore do not care which unit bears the name poundal. The statement that I want to have Claus instead of Rank for the British unit of entropy is wrong. The claus is the unit of entropy in the practical metric system where the joule is the unit of energy. The rank is a name proposed by Prof. Perry for $\int d \mathrm{H} / \theta$, and as this is not entropy in any real change, I cannot adopt it as a unit of entropy. As to $d \chi$, I will deal with that elsewhere; it is a side issue. The statement that I talk of "the entropy of a quantity of heat" is wrong. Prof. Perry holds that entropy is a factor of heat. I dissent, and agree with Prof. Planck that entropy is not a factor of energy. So far from talking of the entropy of a quantity of heat, I have explained very fully how and why entropy is in no sense a factor of heat.

I would not write were a review in NATURE not particularly important, and I trust you will, in fairness to my publishers and myself, allow this letter to appear.

4I Palace Court, W., May I.

James Swinburne.

Mx sole object in the controversy to which Mr. Swinburne refers was to show that, like most of the other writers of whom he complained, I have never either made or championed the mistakes he spealss of at the beginning of this letter. As to my notice of his book, I cannot admit that I have misrepresented him except as to the claus. I made a mistake in saying that his claus is what is sometimes called a rank. As he now says that the momentum of which he spoke was a scalar momentum, I submit that I was quite fair in my comments. I cannot admit that his $\theta \chi$ diagram is a side issue.

JOHN PERRY.

\section{Origin of Plants Common to Europe and America.}

That there is a resemblance between the floras of Canada and northern Europe, and again between the floras of Canada and of eastern Siberia and Japan, is well known. Including the horsetails and ferns with the flowering plants, probably about 575 species are identical in Canada and Europe, and again about 330 in Canada and Japan or the River Amur country. A large number of these are common to the three continents. The hypothesis generally accepted has been that, in some comparatively recent epochs, there has been a connection between Europe and America which facilitated the intermingling of the plant life of the two continents. The late Prof. Asa Gray suggested the probability that the migration of European plants had taken place across Asia to America. Lesquereux, from his studies of the flora of the Dakota group, on the other hand, main tained that the North American flora is not now, nor has it been in past geological ages, the result of migration, but that it is indigenous. It has long been known that species now extinct occurring in the Miocene of Europe had appeared in America at an earlier period. Lester Ward enumerates eleven species-all now extinct--as common to the Laramie group in the United States and the Eocene of Europe, and shows further that at least two living species now found in both Japan and America date their origin in America as far back as the Eocene. Twenty years ago my own studies in the distribution of Canadian plants also convinced me that whilst facilities had existed for migration in both an easterly and a westerly direction, Canada was the point of origin of many of the species now identical in Europe and America. This conviction has been heightened by further knowledge of the range in Canada of these identical species and by further discoveries during recent years of plants in the Pleistocene clays of Canada. Of seventy fossil species in these Pleistocene clays at Toronto, Ottawa and elsewhere, twenty occur at the present day in both Europe and Canada, fourteen are similarly Asiatic and Canadian, whilst eleven are common to the three continents. This, if it does not necessarily indicate that in Pleistocene times the intermingling of these floras had already been effected, at least shows that in this period these identical species were present in Canada, and had

No. 1803 , VOL. 7O] here their place of origin if there is nothing to indicate their presence at as early a period in Europe or Asia. In its vast areas of exposed Laurentian and Huronian formations, Canada has an old look about it, and must have furnished a home through long past ages for the growth and diffusion of northern temperate plant life, when other sections of the globe have from time to time been under water.

The peculiarities of the present range over Canada of many of these identical species also afford suggestions. Whilst many of them are distributed somewhat generally over the country, and many are high northern or Arctic, quite a number do not range west of Lake Superior ; others have not been found west of the Rocky Mountains, whilst some are confined to British Columbia and Alaska. In view of their occurrence also in either Asia or Europe, this circumscribed range of so many species suggests their antiquity, and that the elevation of that lofty barrier, the Rocky Mountains, and the disturbance of the relations of land and water in Manitoba and the North-West Territories in more recent times, has resulted in these plants being confined to their present range where forest conditions were more suitable, and has led to the treeless prairies and plains being tenanted by new groups of species specially suited to the new conditions there, when the land rose to its existing level.

A. T. DRummond.

Toronto, April.

\section{Moisture in the Atmosphere of Mars.}

IN your issue of May 5 I see a note in the astronomical column on Mr. Lowell's theory of the Martian canals. It is perhaps not just to criticise it on so short a summary, but there is a point on which I should like to ask a question. If, as Mr. Lowell says, there is not sufficient moisture on the planet to produce vegetation, how does the water return to the poles ready for the next summer? The only way, it seems to me, is by evaporation. His suggestion of artificial waterways to carry the water from the polar caps implies the existence of an atmosphere sufficiently dense to enable intelligent beings to live. That being so, is it not just as plausible that the evaporated water should condense in the form of rain on the general body of the planet as well as at the poles? although, of course, the excessive cold would account for an increased fall at these extremities.

Bournemouth, May ıo.

Arthur J. Hawkes.

\section{Radium and Milk.}

In the souring of milk the amount of lactic acid developed may reach 0.80 per cent. in three or four days when the milk solidifies. In view of Sir O. Lodge's suggestion (NATURE, October I, I903), I have made experiments comparing the rate of acidification, in two to three days, with and withotit the influence of radium rays from a $5 \mathrm{mgrm}$. radium bromide tube. The differences in five cases did not exceed the limit of experimental error, o.or per cent. of lactic acid, and in a sixth case with the milk solidified the difference only amounted to 0.05 per cent. of lactic acid. It therefore appears to me that under normal conditions radium rays have little or no effect on the functions of the lactic acid bacillus.

William ACKRoyd.

$$
\text { Halifax. }
$$

\section{THE BANTU RACES OF SOUTH AFRICA.'}

NOTHING so good as this book dealing with the 1 Negro indigenes of southern Africa has yet appeared. Mr. Dudley Kidd's work is therefore entitled to take the first rank on this subject, at any rate as far as the Bantu races of South Africa are concerned.

It is a national humiliation to us to reflect that as a Government we have been connected with South Africa for more than a century, that is to say, twothirds as long as our imperial connection with India has lasted, and yet that by Government endeavour or

1 “The Essential Kafir." By Dudley Kidd. Pp. xiii +436 . (London A. and C. Black, 1904.) Price 18 s. net. 
private research so little of value has been published in the English language on the native human races of Africa south of the Zambezi. The present reviewer does not overlook the excellent but incomplete work of the late Dr. Bleek, of Sir George Grey and of McCall Theall, nor should the short work by Theophilus Hahn on the Supreme Being of the Hottentots be left unmentioned. The author of the work under review is also right in calling attention to the value of the Rev. Canon Callaway's work, published in the 'sixties of the last century on the religious system of the Zulus; and the writings of the French Protestant missionary Casalis on the Basuto and Bechuana languages should not be left unrecorded.

The author gives at the end of his book, "The Essential Kafir," a bibliography of the works written in English and French on the Hottentot, Bushmen and Bantu races of Southern Africa. He has omitted to lighten themselves or others on the characteristics of the native races whose doings or misdoings were provocative of so much bloodshed and expenditure of money.

Even those who have left on record their studies of the Negro races in South Africa--with the exception of Dr. Bleek-seem to have carried on those studies with little or no reference to the lands beyond the Zambezi. Many South Africans fancy that the linguistic term Bantu, which was first coined by Dr. Bleek, applies wholly to the Zulu-Kafir-Bechuana peoples of the South African Colonies, and do not realise that it was intended by Dr. Bleek, and has since been used, to cover nearly all that section of the Negro race which inhabits the southern half of Africa between the northern limits of the Congo basin and the Equatorial Lake regions and the eastern districts of Cape Colony. ${ }^{1}$

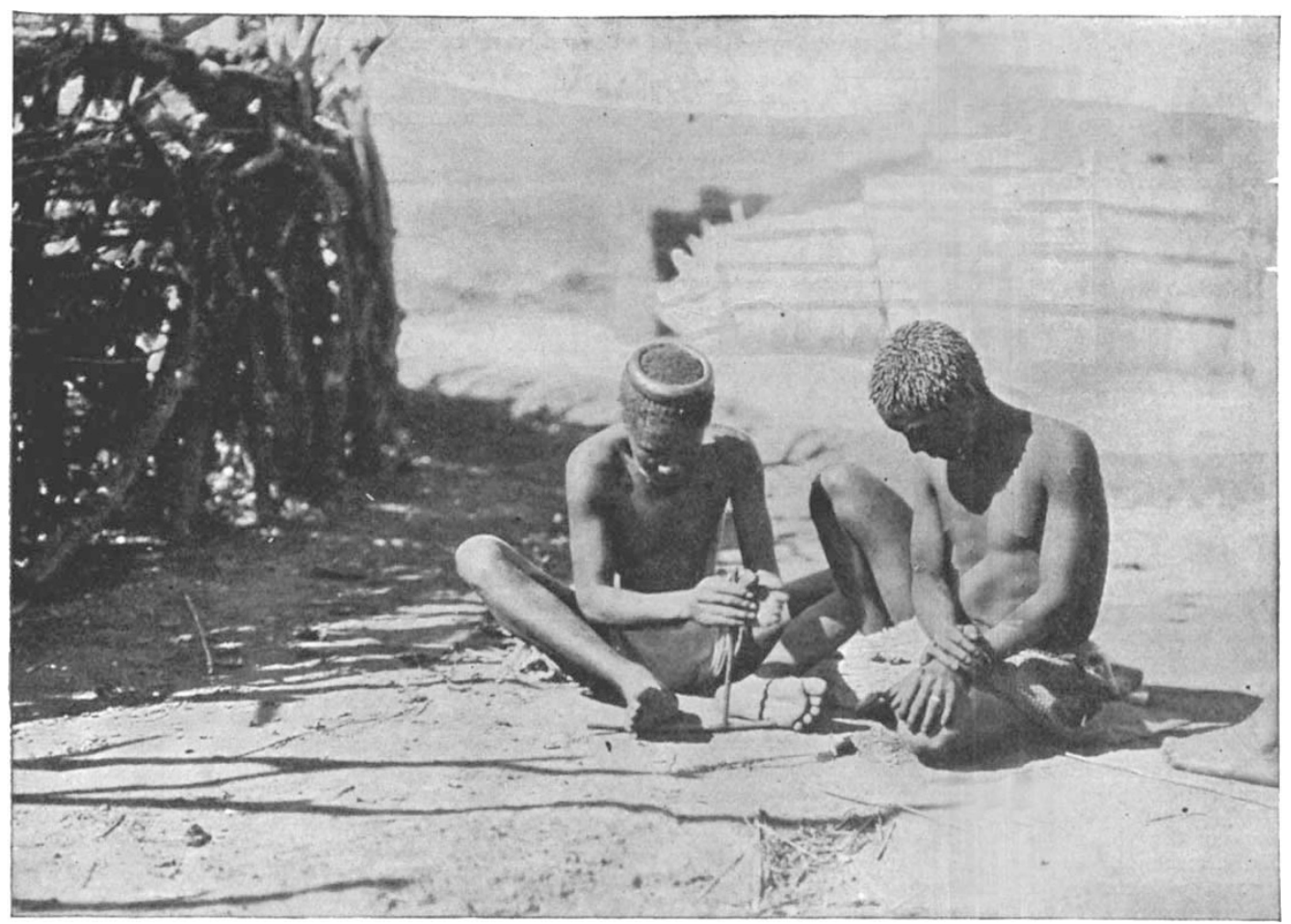

FIG. I.-A Swazie making Fire by Friction. From "The Essential Kafir," by Dudley Kidd.

include a variety of books in the German language on the Damara (Ova-herero) people and language. But these (which are by no means final, comprehensive, or cven particularly valuable) have owed nothing in their inception to the British rule over South Africa. Consequently the slur still remains, especially when we compare such a list as is given in the Appendix to "The Essential Kafir," with a list which might be compiled of works on the native races and languages of India, or even of British Central Africa. It is difficult to understand why scientific Anthropology has played so poor a part in British South Africa; but no doubt it is due to the fact that the great personages, appointed or self-made, who have ruled over or have influenced South Africa during the last hundred years, never, with the exception of Sir George Grey, took the slightest interest in these questions, or cared to en-
Consciously or unconsciously, Mr. Kidd in the book under review brings out emphatically the "Central African" characteristics of the Zulu-Kafir people. (It would be a good thing for consistency of speech if we induced the world at large to drop the term "Kafir," and to apply some such name as Zulu to all those Bantu tribes in South Africa-as apart from the Bechuana, the Herero, and the Zambezi peoplewhich speak dialects of the Zulu language. Kafir -originally spelt Caffre-was the Portuguese rendering of the Arabic " Kafir," plural " Kufar," which means "infidel" or a race not believing in Islam. When the Portuguese vessels first rounded the Cape

1 Dr. Bleek's use of "Bantu" was more connected with linguistic classi1 Dr. Bleek's use of "Bantu" was more connected with linguistic classi-
fications. Whether there is a negro physical type which is connected with fications. Whether there is a negro physical type which is connected with
the making of this distinct group of languages is still undetermined ; Dr. F. the making of this distinct group of languages
Shrubsall, the anthropologist, thinks there is.

No. 1803 , VoL. 70] 
of Good Hope and touched at the coast of south-east Africa, they found Arabs or Arab half-castes trading there, and learning that these called the black natives of the country " Kafirs," they adopted this term henceforth as the designation of the Bantu coast races of southern Africa, and passed on this word to the Dutch, who handed it over to the English. Mr. Kidd, by his excellent and detailed description of Kafir customs, myths, folklore, songs, dances, and implements, shows how inseparable these people are in classification from the Negro races of tropical Africa. This deduction is in varying degrees affected by an examination of South African Bantu languages. Of this subject Mr. Kidd does not treat at any length, but it might be mentioned that a careful study of such linguistic works as those of the late Dr. Bleek brings out the following points :-

A study of the existing languages of the Ova-herero of south-west Africa, of the many Bechuana tribes of central South Africa, and the languages of the ZuluKafirs from Cape Colony on the west and south to the Portuguese district of Inhambane (Nyambane) shows that there is fundamentally a common though remote parentage to these languages so far as the vocabulary and grammatical structure are concerned; that is to say, that there is more evidence of interrelationship between these three groups than there is between any one of them and the Bantu languages to the north and north-east. But there are still very striking differences in phonology between the Herero, Bechuana, and Zulu groups, showing that the history and wanderings of each section must have differed considerably. The Bechuana languages are the most altered from the original Bantu structure, but they are without the clicks which seem to give a Hottentot aspect to the $\mathrm{Zulu}$ dialects, and I believe that very little that is Hottentot can be traced in the etymology of the Bechuana vocabulary. But the phonology of this language is so peculiar as to suggest its great isolation at one period from other Bantu dialects. Some students of Bantu languages, however, have thought that the Bechuana races may have been the pioneers of the Bantu invasion into the regions across the Zambezi.

Physically speaking, the various sections of the Bechuana people exhibit far more traces of intermixture with the Hottentot-Bushmen type than is shown by the Zulu-Kafirs or by the real Herero (Damara) people. ${ }^{1}$ The languages of the Herero group, though they possess marked characteristics in phonology, are of a very pure Bantu type, and gradually link up northwards with the languages of the Congo coast and with the Bantu speech of the southern portions of the Congo basin. The Zulu language retains some primitive characteristics in the form of the prefixes, which have been changed or lost in the Bechuana or Herero groups. Yet in other respects the Zulu dialects have departed widely from the Bantu standard, especially in vocabulary. This language group is a curious mixture of archaic Bantu features and inexplicable elements which, if not "NonBantu," cannot be definitely traced to any known Bantu group of tongues. In a few cases words of this description are of Hottentot origin, but this does not explain many of them, which would appear to have been absolutely invented by the Zulu people, no doubt owing to that strange custom (by no means unknown elsewhere in Africa), of "hlonipa," by which a constant local change of vocabulary takes place owing to the dislike to mentioning names of things which resemble the names of relatives; so that if there

1 Except of course the Hill Damaras, who are a mysterious tribe of mountain people in the northern parts of German South-west Africa-a black race similar in appearance to some of the more degraded Negro tribes of West Africa, but speaking a corrupt dialect of Hottentot. be a prominent person in the tribe, for instance, whose name is actually equivalent to "ox," or even whose name sounds like the word for ox, in that village or community the ox will henceforth be known by a paraphrase or by a substituted word.

In many respects-as Mr. Kidd's work shows over and over again - the Zulu-Kafir race would seem to have been the last arrived of the Bantu peoples in southern Africa, and to have reached that part of the continent at no very remote period-possibly not more than $\mathrm{I}, 500$ to 2,000 years ago. In some of their characteristics the Zulus irresistibly recall the manners and customs of such Nilotic-Negro races as the Masai, though there is absolutely no linguistic connection between the two peoples. No doubt this can be explained by assuming that the original Bantu group from which the Zulu sprang had sent several previous branches to invade South Africa, which may have been the originators of some of the Zambezi tribes, of the Bechuana and the Herero, and that in this original home, somewhere up in east-central Africa, the Zulu peoples came into contact with Nilotic-Negro races from whom they borrowed customs, arms, and methods of warfare, and with whom they shared religious beliefs. When the Zulus started forth on their southward migration their progress seems to have been a relatively rapid one. We need not be astonished at this when we reflect on the remarkable speed with which a small section of the Zulu people in the first decades of the nineteenth century rushed back into Central Africa, reaching in their raids and settlements even the vicinity of the Victoria Nyanza.

The author has much to say of interest on the vexed question of the clicks in Zulu. There are three clicks in this Bantu language-the only Bantu form of speech which possesses these sounds. Some have considered that they were borrowed from the Hottentot, but of late there has been a tendency on the part of students like Mr. Dudley Kidd and Miss A. Werner to argue that these modern clicks in Zulu have been separately developed without Hottentot parentage. Mr. Kidd points out that at the present day the clicks subsist far more in the language of the women than in that of the men. It should be noted that amongst the settlements of Zulus in east-central Africa, which are about seventy years old, the clicks are rapidly disappearing. Dr. Bleek pointed out in his linguistic studies that certain strong intercalated aspirates met with in Swahili, and in one or two other East African Bantu dialects were not dissimilar to a vanishing click.

The space at my disposal does not permit of my dealing further with the interesting problems raised by this book, which, however, I must repeat, is perhaps quite the best that has yet been written or compiled about the Bantu negroes of South Africa. The hundred plates that illustrate this book are all photographs of perfect execution and singular aptness. H. H. JoHnston.

\section{PROF. E. J. MAREY.}

$\mathrm{O}$ $F$ the two veteran Frenchmen who entered on their careers as physiological discoverers half a century ago, Marey and Chauveau, the first has left us. The second is in full vigour and is at this moment engaged in active laboratory work.

Marey died on Sunday night after an illness of much suffering. His earliest investigations had for their purpose the devising of methods by which the arterial pulsations could be made to inscribe themselves on an equably moving surface so as to obtain a graphic record from which their time-relations could be determined. One of the earliest products of these No. I 803 , VOL 70$]$ 